\title{
Analysis of Prognostic Factors Affecting Cancer-specific Survival in Renal Tumors Larger than Ten Centimeters
}

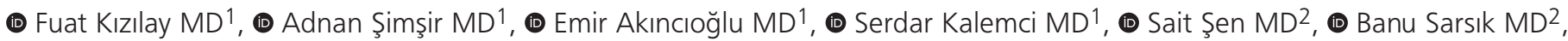 \\ (D) Çağ Çal MD1, (D) Ibrahim Cüreklibatır MD ${ }^{1}$ \\ ${ }^{1}$ Ege University Faculty of Medicine, Department of Urology, Izmir, Turkey \\ 2 Ege University Faculty of Medicine, Department of Pathology, Izmir, Turkey
}

\begin{abstract}
Objective: The aim of this study was to evaluate the relationship between prognostic factors and cancer-specific survival (CSS) in renal tumors larger than ten centimeters.

Materials and Methods: We evaluated the data of 126 patients who underwent open radical nephrectomy due to a renal mass larger than $10 \mathrm{~cm}$ between January 2010 and June 2016. Kaplan-Meier analysis or Cox regression was used to analyze the relationship between CSS and variables. Pairwise group comparisons were also evaluated with the Log-Rank test. A p-value $<0.05$ was considered statistically significant.

Results: Mean follow-up was 68.5 months and mean survival was 39.2 months. The relationships between tumor histopathology, stage and CSS were significant. Tumor size negatively affected CSS, but the relationship was not significant. Tumor stage (T2b, T3b), tumor thrombus, lymph node metastasis and adjuvant therapy were the most effective independent factors affecting CSS according to Cox regression analysis results.

Conclusion: Although tumor size is an important prognostic factor for T2b and lower stage kidney tumors, this effect is less in larger tumors and other clinicopathological features should be considered further to predict prognosis.
\end{abstract}

Keywords: Renal cell carcinoma, prognosis, survival analysis, cancer-specific survival, nephrectomy

\section{Introduction}

Renal cell cancer (RCC) accounts for $2-3 \%$ of all cancers (1). According to World Health Organisation Report 2014, RCC was the $9^{\text {th }}$ and $14^{\text {th }}$ most frequent malign tumor in men and women in 2012, respectively, and the $16^{\text {th }}$ most common cause of cancer-related death worldwide with 143,000 deaths (2). The number of RCCs has increased due to the widespread use of ultrasonography and computed tomography (CT), and these tumors are frequently small and low grade. Although most of these tumors consist of small masses, the number of large masses is quite high.

Factors affecting prognosis in renal tumors can be classified as anatomical, histological, clinical and molecular. Tumor size is an important prognostic factor for RCCs in Tumar, nodes, metostases classification. Some cut-off values for tumor size determine the $T$ stage, such that, $4 \mathrm{~cm}$ and $10 \mathrm{~cm}$ are threshold values for $\mathrm{T} 1 \mathrm{a}$ and $\mathrm{T} 1 \mathrm{~b}$ tumors and $\mathrm{T} 2 \mathrm{a}$ and $\mathrm{T} 2 \mathrm{~b}$ tumors, respectively. Some authors argue that these thresholds do not have prognostic values (3) or that the use of other tumor size thresholds is better (4). Tumor size can also be considered as a threshold value for the proposed cancer treatment as $4 \mathrm{~cm}$ and $3 \mathrm{~cm}$ are widely accepted threshold values for partial nephrectomy and ablative therapies (5). However, in the modern era, these thresholds are not strictly restrictive for experienced surgeons thanks to the development of technological equipment such as robotic surgery.

On the grounds that the prognosis of RCC is variable, many researchers are trying to find prognostic factors that affect RCC survival. As with many cancers, tumor progression and grade are considered to be the most important prognostic factors in RCC. However, it is still unclear which factor and how much it affects the prognosis. In this study, we analyzed the prognostic factors that affect cancer-specific survival (CSS) in kidney tumors larger than $10 \mathrm{~cm}$ and tried to identify the most effective factors.

\section{Materials and Methods}

Patient Selection, Data Collection and Follow-up of the patients one hundred and twenty-six patients who underwent radical 
nephrectomy due to $\geq 10 \mathrm{~cm}$ renal mass and whose pathology report was consistent with RCC between January 2010 and June 2016 were included in the study. Data was obtained from patient files. In localized disease, University of California, Los Angeles (UCLA) integrated staging system (UISS), which was developed by UCLA and combined TNM stage (I to IV), Eastern Cooperative Oncology Group (ECOG) performance status (PS) and Fuhrman degree, were used (6). The Memorial Sloan Kettering Cancer Center (MSKCC) prognostic system, which combines Karnofsky performance status, the interval between diagnosis and treatment, lactate dehydrogenase, corrected calcium, and hemoglobin, was used to determine the risk of recurrence of metastatic disease (7). Tumor pathology, stage, renal vein invasion, perinephric fat invasion, tumor thrombus, lymph node, adrenal and distant organ metastasis status, and ECOG PS Grade of the patient were recorded. Tumor size was calculated from histopathological evaluations because it was more consistent. In order for the histopathological types to be statistically significant, a minimum of seven subjects were required. Therefore, histopathological types less than seven $(n=13)$ were excluded from the study. Tumor staging and nuclear grading were performed according to 2017 TNM classification and Fuhrman's nuclear grading system, respectively (8). Tumor staging and follow-up of patients were performed with enhanced thoracoabdominal CT or magnetic resonance imaging. Patients were subjected to regular controls and CSS rates were calculated. Patients identified as exitus by the hospital system and their exitus dates were also recorded. The present study was conducted in compliance with the Declaration of Helsinki and written informed consent was obtained from the patients. Because of the study was designed as a retrospective study, ethics committee approval was not obtained.

\section{Statistical Analysis}

Kaplan-Meier analysis or Cox regression was used to analyze the relationship between CSS and clinicopathological variables including gender, tumor size, side, location, pathological type, T stage, renal vein invasion, perinephric fat invasion, tumor thrombus, lymph node metastasis, adrenal metastasis, distant organ metastasis, and adjuvant treatment. Pairwise comparisons were evaluated using the Log-Rank test after Kaplan-Meier analysis. Forward stepwise (according to the method of likelihood ratio) multiple logistic regression analysis was used for RCC risk factor analysis. All statistical analyzes were performed using IBM SPSS version 23.0. A p-value $<0.05$ was considered statistically significant.

\section{Results}

A total of 445 patients underwent radical nephrectomy with the diagnosis of renal parenchymal tumors during the study period. The tumor of 307 patients was smaller than $10 \mathrm{~cm}$. Ewing sarcoma $(n=1)$, spindle cell sarcoma $(n=1)$, liposarcoma $(n=1)$, mixed epithelium stromal tumor $(n=1)$, mucinous tubular and spindle cell sarcomas $(n=2)$, neuroectodermal tumors $(n=1)$, neuroendocrine tumors $(n=1)$, pleomorphic sarcomas $(n=1)$, squamous cell carcinomas $(n=1)$ and urothelial carcinomas $(n=2)$ were not included in the study because
Table 1. Demographic data of patients and characteristics of tumors

\begin{tabular}{|c|c|}
\hline Variables & $n^{1}$ \\
\hline Age (year) & $59.10(22-85)$ \\
\hline Gender (female/male) & $38(30.2) / 88(69.8)$ \\
\hline Tumor side (right/left) & $57(45.2) / 69(54.8)$ \\
\hline $\begin{array}{l}\text { Tumor location in the kidney } \\
\text { (upper/middle/lower) }\end{array}$ & $\begin{array}{l}43(34.1) / 32(25.4) / 51 \\
(40.5)\end{array}$ \\
\hline Tumor size $(\mathrm{mm})$ & $128.05(100-220)$ \\
\hline \multicolumn{2}{|l|}{ Histopathological subtypes } \\
\hline Clear cell & $84(66.7)$ \\
\hline Chromophobe cell carcinoma & $18(14.3)$ \\
\hline Papillary tumor & $24(19.0)$ \\
\hline Total & $126(100)$ \\
\hline \multicolumn{2}{|l|}{ Fuhrman grade } \\
\hline Grade 2 & $16(22.2)$ \\
\hline Grade 3 & $37(51.4)$ \\
\hline Grade 4 & $19(26.4)$ \\
\hline \multicolumn{2}{|l|}{ Tumor stages } \\
\hline $\mathrm{T} 2 \mathrm{~b}$ & $40(31.7)$ \\
\hline T3a & 45 (35.7) \\
\hline $\mathrm{T} 3 \mathrm{~b}$ & $10(8.0)$ \\
\hline T4 & $31(24.6)$ \\
\hline Total & $126(100)$ \\
\hline $\begin{array}{l}\text { UCLA integrated staging system risk groups } \\
\text { Low } \\
\text { Intermediate } \\
\text { High }\end{array}$ & $\begin{array}{l}28(28.6) \\
53(54.0) \\
17(17.4) \\
\end{array}$ \\
\hline $\begin{array}{l}\text { MSKCC prognostic system } \\
\text { Low } \\
\text { Intermediate } \\
\text { High }\end{array}$ & $\begin{array}{l}10(35.7) \\
15(53.6) \\
3(10.7) \\
\end{array}$ \\
\hline \multicolumn{2}{|l|}{ Renal vein invasion } \\
\hline Positive & $32(25.4)$ \\
\hline Negative & $94(74.6)$ \\
\hline \multicolumn{2}{|l|}{ Perihilar fat invasion } \\
\hline Positive & $66(52.4)$ \\
\hline Negative & $60(47.6)$ \\
\hline \multicolumn{2}{|l|}{ Tumor thrombus } \\
\hline Positive & $12(9.5)$ \\
\hline Negative & $114(90.5)$ \\
\hline \multicolumn{2}{|l|}{ Metastatic lymph node } \\
\hline Positive & $15(11.9)$ \\
\hline Negative & $111(88.1)$ \\
\hline \multicolumn{2}{|l|}{ Surrenal metastasis } \\
\hline Positive & $11(8.7)$ \\
\hline Negative & $115(91.3)$ \\
\hline \multicolumn{2}{|l|}{ Distant organ metastasis } \\
\hline Positive & $28(22.2)$ \\
\hline Negative & $98(77.8)$ \\
\hline Cancer-specific survival (month) & $39.2(1-168)$ \\
\hline $\begin{array}{l}\text { 'Values are given as numbers and percent or mea } \\
\text { UCLA: University of California, Los Angeles, MSK } \\
\text { Cancer Center }\end{array}$ & $\begin{array}{l}\text { d minimum-maximum } \\
\text { Memorial Sloan Kettering }\end{array}$ \\
\hline
\end{tabular}


the number of cases was insufficient to draw any statistical conclusions. The remaining 126 patients were included in the study. According to the ECOG performance status, 42 patients had grade 0,40 had grade 1, 36 had grade 2, and eight had grade 3 performance status. There were no patients in the $4^{\text {th }}$ grade. The majority of patients had good performance status. Therefore, the survival effect of ECOG status was insignificant. The mean age of the patients was 59.1 years. Most of the patients were male $(88 / 126)$. The mean tumor size was 128.05 $\mathrm{mm}$. The most common histopathological type and Fuhrman grade was clear cell grade $3(29.4 \%)$. Tumors most commonly presented with T3a stage (35.7\%), followed by T2b, T4 and T3b (31.7\%, 24.6\% and $8.0 \%$, respectively). Renal vein invasion was detected in 32 patients (25.4\%). Sixty-six patients $(52.4 \%)$ had perinephric fat invasion. Twelve patients $(9.5 \%)$ had tumor thrombus and 11 patients (8.7\%) had adrenal metastasis. Twenty-eight patients (22.2\%) had distant organ metastases. The mean disease-specific survival was 39.2 (range, 1-168) months. The majority of patients with localized disease was in the UCLA integrated staging system intermediate risk group and the majority of the metastatic patients were in the intermediate group according to the MSKCC prognostic system $(54.0 \%$ and $53.6 \%$, respectively). Patient and tumor characteristics are summarized in Table 1. A total of 87 patients received adjuvant treatment. The multidisciplinary urooncology council determined which treatment should be administered to which patient. Thirty eight of 66 patients with perinephric fat invasion received immunotherapy, seven of 12 patients with tumor thrombosis received targeted therapy, eight of 11 patients with adrenal metastasis received immunotherapy and one of them received targeted therapy, and 20 of 28 patients with distant organ metastasis received immunotherapy and four received targeted therapy. A total of nine patients received adjuvant temsirolimus treatment. Indications and distribution of adjuvant therapy are shown in Table 2.
Although not statistically significant, age negatively affected survival $(p=0.091)$. Fifty-two (59.1\%) men and $22(57.9 \%)$ women died during the follow-up period. Twenty-two patients died due to myocardial infarction, 21 patients due to multiple organ failure as a result of generalized impairment, 19 patients due to acute respiratory distress syndrome and 12 patients due to cerebrovascular disease. The one-year CSS rate was $62.5 \%$ and 5 -year CSS rate was $41.4 \%$ in men. In women, these rates were $75 \%$ and $45.9 \%$, respectively. Mean CSS was 65.7 months for men and 61.3 months for women $(p=0.753)$. Mean CSS was 60.6 months for right-sided tumors and 67.1 months for left-sided tumors $(p=0.900)$. Mean CSS was 68.9 months for lower pole tumors, 52.6 months for middle pole tumors and 42.2 months for upper pole tumors $(p=0.124)$. Renal vein invasion, perinephric fat invasion, tumor thrombus, lymph node metastasis, adrenal metastasis and distant organ metastasis negatively affected mean CSS $(p<0.001, p<0.001$, $\mathrm{p}<0.001, \mathrm{p}<0.001, \mathrm{p}=0.013$, and $\mathrm{p}<0.001$, respectively). Tumor size negatively affected CSS although the relationship was not statistically significant ( $p=0.058$, OR: $1.007,95.0 \% \mathrm{Cl}: 1.000$ 1.014). When survival rates were evaluated according to tumor histopathology, the 1-year CSS rate was $91.7 \%, 77.4 \%, 44.4 \%$, $75 \%$, and $83.3 \%$, for clear cell grade 2 , clear cell grade 3 , clear cell grade 4, chromophobe, and papillary, respectively. Pairwise comparisons of tumor stages were shown in Table 3. Presence of renal vein invasion significantly affected survival $(p<0.001)$. Perinephric fat tissue invasion was also a negative prognostic factor $(p<0.001)$. Tumor thrombosis negatively affected survival $(p<0.001)$ and lymph node metastasis was also a prognostic factor negatively affecting CSS $(p<0.001)$. Estimated CSS in terms of renal vein invasion, perinephric fat tissue, tumor thrombus status and lymph node metastasis status is shown in Figures 1-4.

\begin{tabular}{|l|l|l|l|l|l|}
\hline Table 2. Types and indications of adjuvant therapies \\
\hline $\begin{array}{l}\text { Type of adjuvant } \\
\text { therapy }\end{array}$ & Total number & \multicolumn{2}{l|}{ Indication of adjuvant therapy } & \multicolumn{4}{l|}{} \\
\cline { 2 - 6 } & & Perinephric fat invasion & Tumor thrombosis & Adrenal metastasis & Distant organ metastasis \\
\hline $\begin{array}{l}\text { Immunotherapy } \\
\text { Interferon alpha }\end{array}$ & 66 & 38 & - & 8 & 20 \\
Interleukin-2 & 19 & 12 & & 2 & 5 \\
\hline Targeted therapy & 47 & 26 & 7 & 6 & 15 \\
Sunitinib & 12 & - & 2 & 1 & 4 \\
Cabozantinib & 5 & 4 & 3 & - & 2 \\
Pazopanib & 4 & - & 3 & - & 1 \\
\hline Temsirolimus & 9 & - & 2 & 1 \\
\hline
\end{tabular}

\begin{tabular}{|c|c|c|c|c|c|c|c|c|c|}
\hline & \multirow[t]{2}{*}{ Pathology } & \multicolumn{2}{|l|}{$\mathrm{T} 2 \mathrm{~b}$} & \multicolumn{2}{|l|}{ T3a } & \multicolumn{2}{|l|}{ T3b } & \multicolumn{2}{|l|}{ T4 } \\
\hline & & Chi-square & Sig. & Chi-square & Sig. & Chi-square & Sig. & Chi-square & Sig. \\
\hline \multirow[t]{3}{*}{ Log Rank (Mantel-Cox) } & $\mathrm{T} 2 \mathrm{~b}$ & - & - & 41.015 & $<0.001$ & 8.982 & 0.003 & 45.617 & $<0.001$ \\
\hline & T3a & 41.015 & $<0.001$ & - & - & 0.783 & 0.376 & 0.620 & 0.431 \\
\hline & $\mathrm{T} 3 \mathrm{~b}$ & 8.982 & 0.003 & 0.783 & 0.376 & - & - & 1.700 & 0.192 \\
\hline
\end{tabular}

Statistically significant values are given in bold and italics, Sig: Signetur 
Five and 10-year estimated CSS rates according to the variables are shown in Table 4. The result of the reduced model of Cox regression analysis is given in Table 5, and it revealed that stage $\mathrm{T} 2 \mathrm{~b}$, stage $\mathrm{T} 3 \mathrm{a}$, stage $\mathrm{T} 3 \mathrm{~b}$, tumor thrombus, lymph node metastasis and adjuvant therapy were the most effective factors for CSS (HR=6.644, 2.358, 8.164, 3.149, 5.143, 6.188, and 2.014, respectively).

\section{Discussion}

RCC constitutes approximately $85 \%$ of primary renal cancers. As with all cancers, predicting prognosis in RCC is important for treatment management. In RCC patients, TNM stage, tumor nuclear grade and RCC subtype provide important prognostic information. Prognostic factors in renal cancers can be classified as anatomical, histological, clinical and

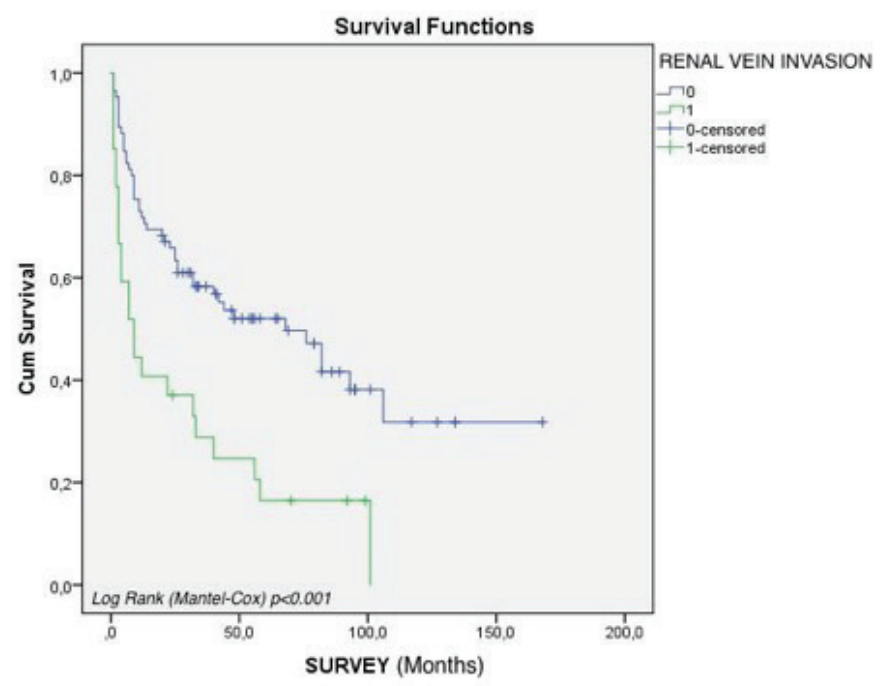

Figure 1. Kaplan-Meier survival curve of cancer-specific survival with and without renal vein invasion

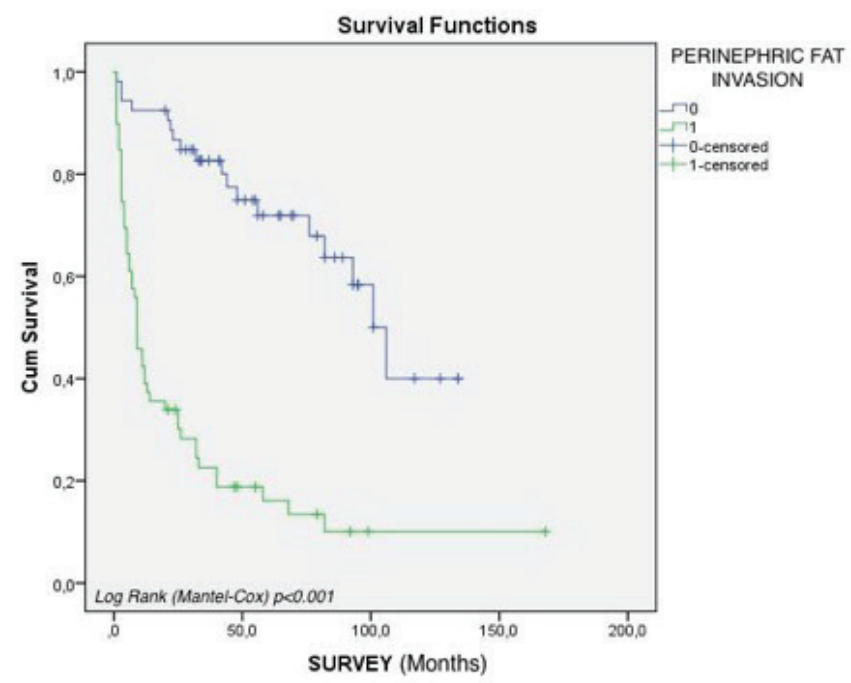

Figure 2. Kaplan-Meier survival curve of cancer-specific survival with and without perinephric fat tissue invasion molecular. Accurate staging is very important in order to decide the treatment of these tumors and to predict prognosis and response to treatment. Pathological staging determines the anatomic spread of the tumor and its relationship with the surrounding tissues. Tumor size in the TNM system used for the staging of renal tumors is one of the most important prognostic factors. Tumor size is not only a prognostic marker; it is also a determining factor for the type (partial/radical) and method of operation (open/laparoscopic). In the literature, the prognostic factors for $\mathrm{T} 1(\leq 7 \mathrm{~cm})$ and $\mathrm{T} 2(\leq 10 \mathrm{~cm})$ tumors are well established and there are many studies in this regard. However, there is uncertainty about the prognosis and surgical methods of renal masses larger than $10 \mathrm{~cm}$. For this reason, in the present study, we performed a survival analysis by evaluating prognostic factors in renal tumors larger than $10 \mathrm{~cm}$ that underwent surgical treatment in our clinic and we aimed

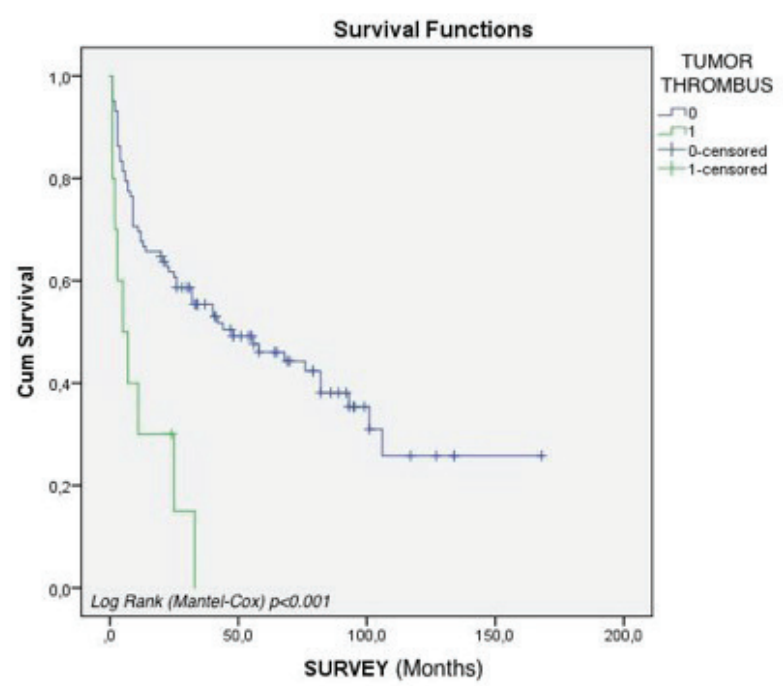

Figure 3. Kaplan-Meier survival curve of cancer-specific survival with and without tumor thrombus

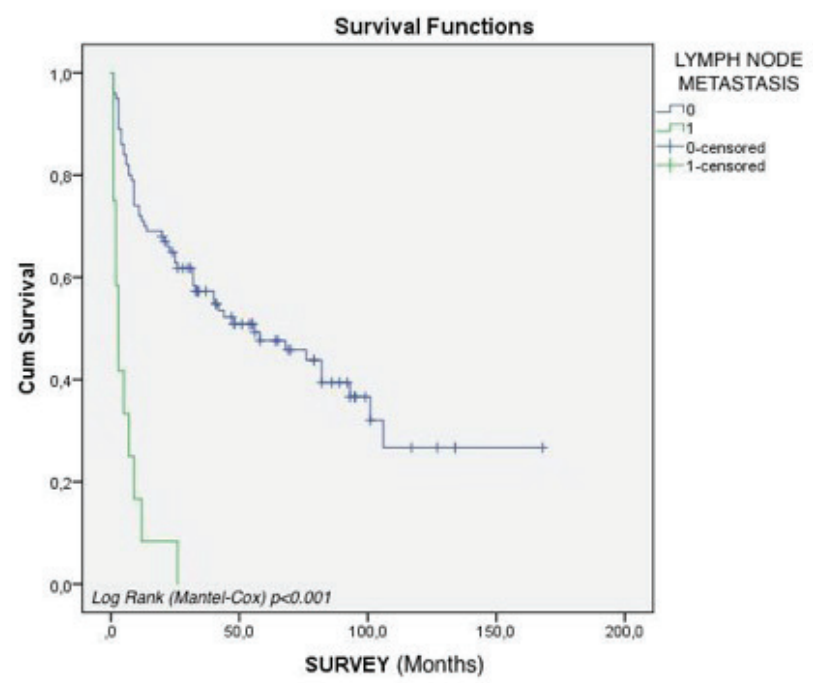

Figure 4. Kaplan-Meier survival curve of cancer-specific survival with and without lymph node metastasis 


\begin{tabular}{|c|c|c|c|c|c|}
\hline \multirow[t]{2}{*}{ Variables } & \multirow[t]{2}{*}{ Time $^{1}$} & \multicolumn{2}{|c|}{$\begin{array}{l}\text { Cumulative } \\
\text { proportion } \\
\text { surviving at } \\
\text { the time }\end{array}$} & \multirow[t]{2}{*}{$\begin{array}{l}\text { Number of } \\
\text { Cumulative } \\
\text { events }\end{array}$} & \multirow[t]{2}{*}{$\begin{array}{l}\text { Number of } \\
\text { Remaining } \\
\text { events }\end{array}$} \\
\hline & & Est. & SE & & \\
\hline \multicolumn{6}{|l|}{ Gender } \\
\hline Male & a & 0.414 & 0.058 & 45 & 19 \\
\hline Female & b & 0.239 & 0.090 & 48 & 3 \\
\hline \multicolumn{6}{|l|}{ Tumor side } \\
\hline \multirow[t]{2}{*}{ Right } & a & 0.432 & 0.077 & 26 & 12 \\
\hline & b & 0.314 & 0.081 & 29 & 8 \\
\hline \multirow[t]{2}{*}{ Left } & a & 0.438 & 0.069 & 31 & 16 \\
\hline & b & 0.219 & 0.089 & 35 & 3 \\
\hline \multicolumn{6}{|l|}{ Tumor location } \\
\hline \multirow[t]{2}{*}{ Lower } & a & 0.505 & 0.087 & 17 & 14 \\
\hline & b & 0.280 & 0.101 & 21 & 4 \\
\hline \multirow[t]{2}{*}{ Middle } & a & 0.357 & 0.110 & 13 & 6 \\
\hline & b & 0.143 & 0.090 & 16 & 2 \\
\hline \multirow[t]{2}{*}{ Upper } & a & 0.329 & 0.101 & 17 & 5 \\
\hline & b & - & - & - & - \\
\hline \multicolumn{6}{|l|}{ Pathology } \\
\hline \multirow{2}{*}{$\begin{array}{l}\text { Clear cell } \\
\text { grade } 2\end{array}$} & a & 0.625 & 0.155 & 4 & 5 \\
\hline & b & 0.313 & 0.174 & 6 & 1 \\
\hline \multirow{2}{*}{$\begin{array}{l}\text { Clear cell } \\
\text { grade } 3\end{array}$} & a & 0.367 & 0.093 & 18 & 8 \\
\hline & b & 0.000 & 0.000 & 22 & 0 \\
\hline \multirow{2}{*}{$\begin{array}{l}\text { Clear cell } \\
\text { grade } 4\end{array}$} & a & 0.292 & 0.120 & 12 & 2 \\
\hline & b & - & - & - & - \\
\hline \multirow{2}{*}{ Chromophobe } & a & 1.000 & 1.000 & 0 & 7 \\
\hline & b & 0.750 & 0.217 & 1 & 1 \\
\hline \multirow{2}{*}{$\begin{array}{l}\text { Papillary } \\
\text { tumor }\end{array}$} & a & 0.729 & 0.135 & 3 & 5 \\
\hline & $\mathrm{b}$ & 0.729 & 0.135 & 3 & 2 \\
\hline \multicolumn{6}{|l|}{ Stage } \\
\hline \multirow[t]{2}{*}{$\mathrm{T} 2 \mathrm{~b}$} & a & 0.936 & 0.044 & 2 & 20 \\
\hline & b & 0.520 & 0.172 & 7 & 3 \\
\hline \multirow[t]{2}{*}{ T3a } & a & 0.267 & 0.226 & 3 & 0 \\
\hline & b & 0.080 & 0.065 & 33 & 1 \\
\hline \multirow[t]{2}{*}{ T3b } & a & 0.160 & 0.065 & 32 & 4 \\
\hline & b & - & - & - & - \\
\hline \multirow[t]{2}{*}{$\mathrm{T} 4$} & a & 0.132 & 0.069 & 22 & 3 \\
\hline & b & 0.066 & 0.058 & 23 & 0 \\
\hline
\end{tabular}

\begin{tabular}{|c|c|c|c|c|c|}
\hline \multicolumn{6}{|c|}{ Fuhrman grade } \\
\hline \multirow[t]{2}{*}{ Grade 2} & $\mathrm{a}$ & 0.683 & 0.290 & 1 & 9 \\
\hline & $b$ & 0.322 & 0.317 & 3 & 3 \\
\hline \multirow[t]{2}{*}{ Grade 3} & $\mathrm{a}$ & 0.481 & 0.599 & 7 & 14 \\
\hline & $b$ & 0.209 & 0.614 & 10 & 6 \\
\hline \multirow[t]{2}{*}{ Grade 4} & $\mathrm{a}$ & 0.102 & 0.201 & 16 & 3 \\
\hline & $b$ & - & - & - & - \\
\hline \multicolumn{6}{|c|}{ Renal vein invasion } \\
\hline \multirow[t]{2}{*}{ Negative } & a & 0.520 & 0.057 & 39 & 32 \\
\hline & $\mathrm{b}$ & 0.318 & 0.081 & 45 & 4 \\
\hline \multirow[t]{2}{*}{ Positive } & $a$ & 0.165 & 0.074 & 22 & 4 \\
\hline & $\mathrm{b}$ & 0.000 & 0.000 & 23 & 0 \\
\hline \multicolumn{6}{|c|}{ Perinephric fat invasion } \\
\hline \multirow[t]{2}{*}{ Negative } & $\mathrm{a}$ & 0.719 & 0.068 & 13 & 22 \\
\hline & $b$ & 0.400 & 0.125 & 18 & 3 \\
\hline \multirow[t]{2}{*}{ Positive } & $\mathrm{a}$ & 0.161 & 0.051 & 48 & 6 \\
\hline & $\mathrm{b}$ & 0.101 & 0.047 & 50 & 1 \\
\hline \multicolumn{6}{|c|}{ Tumor thrombus } \\
\hline \multirow[t]{2}{*}{ Negative } & $\mathrm{a}$ & 0.460 & 0.053 & 52 & 28 \\
\hline & $\mathrm{b}$ & 0.258 & 0.072 & 59 & 4 \\
\hline Positive & $\mathrm{a}$ & 0.000 & 0.000 & 9 & 0 \\
\hline \multicolumn{6}{|c|}{ Lymph node metastasis } \\
\hline \multirow[t]{2}{*}{ Negative } & $\mathrm{a}$ & 0.476 & 0.054 & 49 & 28 \\
\hline & $\mathrm{b}$ & 0.267 & 0.075 & 56 & 4 \\
\hline Positive & a & 0.000 & 0.000 & 12 & 0 \\
\hline \multicolumn{6}{|c|}{ Adrenal metastases } \\
\hline \multirow[t]{2}{*}{ Negative } & a & 0.459 & 0.053 & 52 & 27 \\
\hline & $\mathrm{b}$ & 0.238 & 0.077 & 59 & 4 \\
\hline \multirow[t]{2}{*}{ Positive } & $\mathrm{a}$ & 0.100 & 0.095 & 9 & 1 \\
\hline & $b$ & - & - & - & - \\
\hline \multicolumn{6}{|c|}{ Distant organ metastasis } \\
\hline \multirow[t]{2}{*}{ Negative } & $a$ & 0.667 & 0.098 & 9 & 10 \\
\hline & $b$ & 0.000 & 0.000 & 14 & 0 \\
\hline Positive & $\mathrm{a}$ & 0.000 & 0.000 & 26 & 0 \\
\hline \multicolumn{6}{|c|}{ UCLA integrated staging system (UISS) risk group } \\
\hline \multirow[t]{2}{*}{ Low } & $\mathrm{a}$ & 0.732 & 0.291 & 2 & 18 \\
\hline & $\mathrm{b}$ & 0.489 & 0.217 & 4 & 12 \\
\hline \multirow[t]{2}{*}{ Intermediate } & $\mathrm{a}$ & 0.602 & 0.117 & 8 & 21 \\
\hline & $b$ & 0.311 & 0.086 & 13 & 10 \\
\hline High & a & 0.218 & 0.014 & 22 & 0 \\
\hline
\end{tabular}




\begin{tabular}{|c|c|c|c|c|c|}
\hline \multicolumn{6}{|c|}{ MSKCC prognostic system } \\
\hline Low & a & 0.418 & 0.372 & 8 & 2 \\
\hline Intermediate & a & 0.000 & 0.000 & 15 & 0 \\
\hline High & $a$ & 0.000 & 0.000 & 3 & 0 \\
\hline \multicolumn{6}{|c|}{ Adjuvant theraphy } \\
\hline \multirow{2}{*}{$\begin{array}{l}\text { Negative } \\
\text { Positive }\end{array}$} & a & 0.748 & 0.039 & 22 & 8 \\
\hline & $\mathrm{b}$ & 0.411 & 0.102 & 7 & 2 \\
\hline Immunotheraphy & a & 0.000 & 0.000 & 66 & 0 \\
\hline Targeted theraphy & a & 0.000 & 0.000 & 21 & 0 \\
\hline \multicolumn{6}{|c|}{$\begin{array}{l}\text { "Time is given in months. " } \mathrm{a} \text { " indicates the } 60 \text {-months period and " } \mathrm{b} \text { " indicates } \\
\text { the } 120 \text {-months period. } 120 \text { months survival (b) was not given for the variables } \\
\text { with a survival rate of } 0 \text { at } 60 \text { months. } \\
\text { Est: Estimated, SE: Standard error, UCLA: University of California, Los Angeles, } \\
\text { UISS: UCLA integrated staging system, MSKCC: Memorial Sloan Kettering } \\
\text { Cancer Center }\end{array}$} \\
\hline
\end{tabular}

Table 5. Results of multivariate Cox proportional-hazards regression analysis of factors correlated with cancer-specific survival

\begin{tabular}{|c|c|c|c|c|}
\hline \multirow[b]{2}{*}{ Variables } & \multirow[b]{2}{*}{ Sig. ${ }^{1}$} & \multirow[b]{2}{*}{$\operatorname{Exp}(B)$} & \multicolumn{2}{|c|}{ 95\% Cl for Exp (B) } \\
\hline & & & Lower & Upper \\
\hline Tumor size & 0.001 & 1.014 & 1.005 & 1.022 \\
\hline Stage $T 2 b$ & 0.018 & 6.644 & 1.392 & 31.698 \\
\hline Stage T3a & 0.421 & 2.358 & 0.292 & 19.070 \\
\hline Stage T3b & 0.009 & 8.164 & 1.704 & 39.127 \\
\hline Tumor thrombus & - & - & - & - \\
\hline Negative (12) & - & - & - & - \\
\hline Positive (114) & 0.012 & 3.149 & 1.291 & 7.681 \\
\hline Lymph node metastasis & - & - & - & - \\
\hline Negative (111) & - & - & - & - \\
\hline Positive (15) & $<0.001$ & 5.143 & 2.426 & 10.902 \\
\hline Adjuvant therapy & - & - & - & - \\
\hline Immunotherapy & 0.024 & 6.188 & 5.724 & 6.481 \\
\hline Targeted therapy & 0.039 & 2.014 & 1.884 & 2.414 \\
\hline
\end{tabular}

to evaluate the prognostic factors for these masses. In our study, we used the current TNM classification system for staging purpose (8). Prognostic systems and nomograms may predict survival better than TNM classification or Fuhrman's grading system alone in localized and metastatic diseases in patients with RCC. We used the UISS developed by UCLA for localized disease. In metastatic disease, classification systems such as the MSKCC prognostic system and Hang's model are available. We used MSKCC prognostic system to assess recurrence risk in metastatic patients.

Tumor size has been addressed in many studies. In a study of 360 patients, Kunkle et al. (9) showed that every $1 \mathrm{~cm}$ increase in all tumor sizes increased the incidence of metastatic disease by $22 \%$. In another study, it was shown that the life expectancy was dependent on tumor size and the survival rate was $84 \%$ in $<5 \mathrm{~cm}$ tumors and $0 \%$ in $>10 \mathrm{~cm}$ tumors (10). Similarly, although the relationship was not significant, tumor size and survival were inversely proportional in our study $(p=0.058)$. The Fuhrman grade is the most widely accepted grading system in RCC grading and is an independent prognostic factor (11). Fuhrman grade was also an important factor affecting CSS in our cohort.

T stage is one of the important prognostic factors for RCC. Amin et al. (12) defined T stage as an independent predictor of aggressive clinical phenotype, defined as local recurrence, metastasis development and death from disease in chromophobe RCC. It is a well-established data that T1 stage causes higher CSS than T2-4. Bianchi et al. (4) reported a 5-year CSS rate of $80.7-86.2 \%$ for the 4,963 T2-stage RCC cases undergoing surgical treatment. Kopp et al. (13) also reported a 5-year CSS rate of $82.5-86.7 \%$ in $202 \mathrm{~T} 2$-stage RCC treated at multiple centers. In our results, the 5-year survival rate for stage T2 was $93 \%$. The reason that this result is more optimistic may be due to the fact that the patients in the above studies are collected from different centers and that the patient groups were not homogeneously distributed. Laird et al. (14) found a 5-year survival rate of $64.4-67.3 \%$ for 252 stage T3 RCC cases from the British medical center. In two other studies, the 5-year CSS rate for T3 stage RCC was reported to be $46-51.1 \%(15,16)$. In our cohort, the 5 -year CSS rate for stage T3a was $26 \%$ and $16 \%$ for T3b. Probably; the reason why these rates were lower than other studies are that we often have to operate these patients with cardiovascular surgeons. However, sometimes we have difficulties to organize together and the surgical procedure may be delayed.

Many drugs have shown clinical benefit in metastatic RCC. Recently, the efficacy of the immune-checkpoint inhibitors has been shown, as well as immunotherapy and targeted therapy. A recurrence rate of $35 \%$ despite surgical resection underlines the importance of these treatments (17). Prior to the use of tyrosine kinase inhibitors (TKIs), INF- $\alpha$ and IL-2 were the standard treatment of metastatic RCC. In the analysis of six prospective studies, Motzer et al. (18) showed a 13-month overall survival advantage in patients treated with INF- $\alpha$. Identification of the von Hippel-Lindau gene has shed light on the understanding of RCC pathogenesis. However, targeting of angiogenesis and Mammalian terget of Rapamycin (mTOR) pathway has provided benefit in clinical outcomes. These agents include vascular endothelial growth factor receptor TKIs (sunitinib, pazopanib, axitinib, sorafenib) and mTOR inhibitors (temsirolimus and everolimus) $(19,20)$. In our study, 87 patients received adjuvant therapy and adjuvant therapy was an important factor affecting CSS. This result also supports the efficacy of adjuvant therapy in tumors larger than $10 \mathrm{~cm}$.

A large multicenter study analyzed 291 chromophobe-cell RCCs and suggested that gender was an independent predictor of CSS, and reported that female patients had a significantly lower risk of dying from the disease (21). In our study, on the contrary, the mean CSS rate was higher in males (65.7 vs 61.3 ), but the difference was not significant $(p=0.753)$. 
The relationship between tumor histopathology and survival has been examined in many studies and conflicting results have emerged. There are single-center studies reporting that the survival of chromophobe RCC is better than that of conventional RCC $(22,23)$. However, in large, multicenter series, tumor histology has not been identified as an independent prognostic factor $(24,25)$. Our results revealed that the histological type was an important prognostic factor and affected survival significantly.

In a single-center survival analysis of 1326 patients from China, the tumor thrombus [renal vein or inferior vena cava (IVC)] was a prognostic factor, but the level of IVC involvement was not associated with prognosis (26). Previously, controversial results have been reported about the relationship between IVC thrombus level and tumor prognosis. In our study, we did not stratify the level of thrombus, but tumor thrombus was an important prognostic factor for survival and one of the most important factors affecting CSS in multivariate analysis.

Siddiqui et al. (27) evaluated the prognostic value of perinephric fat invasion and concluded that it was a negative prognostic factor in all tumor sizes and that it was unnecessary to utilize the tumor size for grouping the T3a stage. On the other hand, Yoo et al. (28) found that $>7 \mathrm{~cm}$ pT3a tumors had a worse prognosis than $\leq 7 \mathrm{~cm}$ pT3a tumors and concluded that tumor size should be included for more accurate staging for patients with perinephric fat tissue invasion. Murphy et al. (29) compared stage T2 and T3a patients according to clinicopathological features and pointed out that tumor size was a more significant prognostic factor than perinephric fat invasion. Gofrit et al. (30) also advocated that perinephric fat invasion was an insignificant prognostic factor, and in the new TNM staging system that they proposed, they excluded perinephric fat invasion and included tumor size and venous involvement. Our results, similar to the last two studies, confirmed that perinephric fat invasion was an important prognostic factor for survival alone, but not an independent factor in Cox regression analysis.

Tumor size is very important in the T staging of renal tumors and provides important information about prognosis, treatment method and survival. There are many studies mentioned above in which T1 and T2 stage renal tumors were stratified and the relationship between tumor size and other important prognostic factors was analyzed. In this study, we focused on T2b-stage tumors and evaluated the relationship between prognostic factors and survival. In the light of our study, perhaps further stages between $\mathrm{T} 2 \mathrm{~b}$ and $\mathrm{T} 3$ may be identified in the future with prospective, randomized, large patient group studies.

Our study is unique since it was the first study to evaluate prognostic factors in kidney tumors over $10 \mathrm{~cm}$ in diameter. The evaluation of pathologic specimens by an experienced, single genitourinary pathologist is a significant advantage of our study. Our study also had some limitations. Although the patient data were carefully reviewed from the files, the retrospective nature of the study and relatively small patient group were the main drawbacks. A total of 87 patients out of 126 received adjuvant treatment and this was a confounding variable that might affect the result. Another important limitation was the absence of a comparison group and that might have generated a selection bias.

\section{Conclusion}

Tumor size is an important factor affecting the treatment modalities, technique and prognosis in $\mathrm{T} 1$ and $\mathrm{T} 2$ stage tumors. However, our results showed that this effect was minimal and other clinicopathological features were important in $\mathrm{T} 2 \mathrm{~b}$ and higher stage tumors. Adjuvant therapy was also found to be a significant factor affecting CSS. Prospective studies are needed for a higher level of evidence.

\section{Ethics}

Ethics Committee Approval: Because of the study was designed as a retrospective study, ethics committee approval was not obtained.

Informed Consent: Written informed consent was taken from all patients in order to be able to use their data in scientific studies without revealing their private information.

Peer-review: Externally peer-reviewed.

\section{Authorship Contributions}

Surgical and Medical Practices: F.K., A.S.., E.A., S.K., S.Ş., B.S., Ç.Ç., I.C., Concept: F.K., A.Ş., Design: F.K., A.Ş., Data Collection or Processing: F.K., A.Ş., E.A., S.K., S.Ş., B.S., Analysis or Interpretation: F.K., A.Ş., E.A., S.K., S.S., B.S., Ç.Ç., I.C., Literature Search: F.K., Writing: F.K.

Conflict of Interest: No conflict of interest was declared by the authors.

Financial Disclosure: The authors declared that this study received no financial support.

\section{References}

1. Siesling S, Louwman WJ, Kwast A, et al. Uses of cancer registries for public health and clinical research in Europe: Results of the European Network of Cancer Registries survey among 161 population-based cancer registries during 2010-2012. Eur J Cancer 2015;51:1039-1049.

2. McGuire S. World cancer report 2014. Geneva, Switzerland: World Health Organization, international agency for research on cancer, WHO Press, 2015. Adv Nutr 2016;7:418-419.

3. Waalkes S, Becker F, Schrader AJ, et al. Is there a need to further subclassify pT2 renal cell cancers as implemented by the revised 7 th TNM version? Eur Urol 2011; 59:258-263.

4. Bianchi M, Becker A, Trinh QD, et al. An analysis of patients with $T 2$ renal cell carcinoma (RCC) according to tumour size: a populationbased analysis. BJU Int 2013;111:1184-1190.

5. Varkarakis IM, Allaf ME, Inagaki T, et al. Percutaneous radio frequency ablation of renal masses: results at a 2-year mean followup. J Urol 2005; 174:456-460.

6. Zisman A, Pantuck AJ, Dorey F, et al. Improved prognostication of renal cell carcinoma using an integrated staging system. J Clin Oncol 2001;19:1649-1657.

7. Motzer RJ, Mazumdar M, Bacik J, et al. Survival and prognostic stratification of 670 patients with advanced renal cell carcinoma. I Clin Oncol 1999;1 7:2530-2540.

8. Gospodarowicz MK, Brierley JD, Wittekind C. TNM classification of malignant tumours. John Wiley Sons; 2017. 
9. Kunkle DA, Crispen PL, Li T, Uzzo RG. Tumor size predicts synchronous metastatic renal cell carcinoma: implications for surveillance of small renal masses. J Urol 2007;177:1692-1696.

10. Guinan P, Saffrin R, Stuhldreher D, et al. Renal cell carcinoma: comparison of the TNM and Robson stage groupings. J Surg Oncol 1995;59:186-189.

11. Fuhrman SA, Lasky LC, Limas C. Prognostic significance of morphologic parameters in renal cell carcinoma. Am J Surg Pathol 1982;6:655-663.

12. Amin MB, Paner GP, Alvarado-Cabrero I, et al. Chromophobe renal cell carcinoma: histomorphologic characteristics and evaluation of conventional pathologic prognostic parameters in 145 cases. Am J Surg Pathol 2008;32:1822-1834.

13. Kopp RP, Mehrazin R, Palazzi KL, et al. Survival outcomes after radical and partial nephrectomy for clinical T2 renal tumours categorised by R.E.N.A.L nephrometry score. BJU Int 2014;114:708-718.

14. Laird A, Choy K, Delaney $H$, et al. Matched pair analysis of laparoscopic versus open radical nephrectomy for the treatment of T3 renal cell carcinoma. World J Urol 2015;33:25-32.

15. Stewart GD, Ang WJ, Laird A, et al. The operative safety and oncological outcomes of laparoscopic nephrectomy for T3 renal cell cancer. BJU Int 2012;110:884-890.

16. Lam JS, Klatte T, Patard JJ, et al. Prognostic relevance of tumour size in T3a renal cell carcinoma: a multicentre experience. Eur Urol 2007;52:155-162.

17. Siegel RL, Miller KD, Jemal A. Cancer statistics, 2016. CA Cancer J Clin 2016; 66:7-30.

18. Motzer RJ, Bacik J, Murphy BA, et al. Interferon-alfa as a comparative treatment for clinical trials of new therapies against advanced renal cell carcinoma. J Clin Oncol 2002;20:289-296.

19. Sternberg CN, Davis ID, Mardiak J, et al. Pazopanib in locally advanced or metastatic renal cell carcinoma: results of a randomized phase III trial. J Clin Oncol 2010;28:1061-1068.
20. Motzer RJ, Escudier B, Oudard S, et al. Efficacy of everolimus in advanced renal cell carcinoma: a double-blind, randomised, placebocontrolled phase III trial. Lancet 2008;372:449-456.

21. Volpe A, Novara G, Antonelli A, et al. Chromophobe renal cell carcinoma (RCC): oncological outcomes and prognostic factors in a large multicentre series. BJU Int 2012;110:76-83.

22. Beck SD, Patel MI, Snyder ME, et al. Effect of papillary and chromophobe cell type on disease-free survival after nephrectomy for renal cell carcinoma. Ann Surg Oncol 2004;11:71-77.

23. Cheville JC, Lohse CM, Zincke $H$, et al. Comparisons of outcome and prognostic features among histologic subtypes of renal cell carcinoma. Am J Surg Pathol 2003;27:612-624.

24. Crépel $M$, Isbarn $H$, Capitanio $U$, et al. Does histologic subtype affect oncologic outcomes after nephron-sparing surgery? Urology 2009;74:842-845.

25. Patard JJ, Leray E, Cindolo L, et al. Multi-institutional validation of a symptom based classification for renal cell carcinoma. J Urol 2004; 172:858-862.

26. Zhang $\mathrm{Y}, \mathrm{Yu} \mathrm{H}$, Li H. Survival analysis of surgically treated renal cell carcinoma: a single Chinese medical center experience from 2002 to 2012. Int Urol Nephrol 2015;47:1327-1333.

27. Siddiqui SA, Frank I, Leibovich BC, et al. Impact of tumor size on the predictive ability of the pT3a primary tumor classification for renal cell carcinoma. J Urol 2007;177:59-62.

28. Yoo C, Song C, Hong JH, et al. Prognostic significance of perinephric fat infiltration and tumor size in renal cell carcinoma. J Urol 2008; 180:486-491.

29. Murphy AM, Gilbert SM, Katz AE, et al. Re-evaluation of the TumourNode-Metastasis staging of locally advanced renal cortical tumours: absolute size (T2) is more significant than renal capsular invasion (T3a). BJU Int 2005;95:27-30.

30. Gofrit ON, Shapiro A, Pizov G, et al. Does stage T3a renal cell carcinoma embrace a homogeneous group of patients? J Urol 2007; 177:1682-1686. 